\title{
Criopreservação de sêmen humano - comparação entre métodos de congelação e tipos de envase
}

\section{(Cryopreservation of human semen comparison between methods of freezing and types of storage)}

Aluno: Marcelo Borges Cavalcante.

Orientador: Prof. Dr. Eugênio Pacelli de Barreto Teles

Dissertação de Mestrado em Tocoginecologia, apresentado ao Departamento de Saúde Materno-Infantil da Faculdade de Medicina da Universidade Federal do Ceará, em 20 de dezembro de 2004.

Objetivo: determinar o melhor método de criopreservação de sêmen humano, comparando método rápido com lento e envase em palhetas de $0,25 \mathrm{~mL}$ com criotubos de $2 \mathrm{~mL}$, utilizando como variáveis a morfologia e motilidade espermática. Método: estudo experimental, de validação de técnica laboratorial. desenvolvido no Centro de Reprodução Assistida do Ceará. Analisadas dezoito amostras de sêmen de dezoito voluntários. As amostras foram submetidas à análise da morfologia e motilidade prévia à criopreservação. Foi determinada uma curva de motilidade nas primeiras três horas. Depois de adicionado o crioprotetor (Test-Yolk), o sêmen foi dividido em partes iguais e envasado em criotubos e palhetas. Metade dos criotubos e das palhetas foi criopreservada pelo método rápido (RT e RP, respectivamente) e a outra metade pelo lento (LT e LP). As amostras foram descongeladas e determinadas as morfologias e motilidades logo após a descongelação e a cada hora durante três horas.
Foi utilizado o programa SPSS Windows 11.0.0. Resultados: diminuição significante da motilidade após a criopreservação, inicial de 58,1\% e motilidades nos diferentes tratamentos de 30,3\% (LT), 21,1\% (LP), 27\% (RT) e $19,2 \%$ (RP). Houve queda significante da morfologia normal após a criopreservação, em relação à inicial $(14,2 \%)$, não foi observada diferença entre os métodos $(12,8,12,6,12,6 \%$ e $12,4 \%$; RP, RT, LP e LT, respectivamente). O método LT obteve uma curva de motilidade espermática próxima da observada no sêmen in natura. Conclusão: o método LT foi o que menos afetou a motilidade espermática. A criopreservação piorou da morfologia espermática de forma semelhante nos métodos estudados.

PALAVRAS-CHAVE: Criopreservação; Espermatozóide; Preservação do Sêmen; Infertilidade

Resumo de Tese

\section{Estudo da atividade proliferativa do epitélio mamário normal de mulheres no menacme tratadas com raloxifeno utilizando o marcador celular Ki-67}

\section{Study of proliferative activity in normal breast epithelium of women in the menacme treated with raloxifene using the marker Ki-67}

Autora: Ione Maria Ribeiro Soares Lopes

Orientador: Prof. Dr. Benedito Borges da Silva

Dissertação de Mestrado em Ciências e Saúde, apresentada à Universidade Federal do Piauí, em 3 de fevereiro de 2005.

Introdução: $O$ raloxifeno é um modulador seletivo do receptor estrogênico com uso aprovado na prevenção e tratamento da osteoporose. Em estudos clínicos e epidemiológicos tem mostrado uma redução na incidência do câncer de mama. Objetivo: Avaliar a ação do raloxifeno no epitélio mamário normal, de mulheres no menacme. Metodologia: estudaram-se, de forma aleatória e duplo-cega, 30 mulheres portadoras de fibroadenoma mamário, divididas em dois grupos: Grupo I ( $\mathrm{n}=16$; controle) e Grupo II ( $\mathrm{n}=14$; raloxifeno $60 \mathrm{mg} /$ dia). O tratamento foi iniciado no primeiro dia do ciclo menstrual e as cirurgias para a exérese dos fibroadenomas e tecidos adjacentes foram realizadas no $22^{\circ}$ dia do ciclo, quando então foi dosada a progesterona. Foram estudadas as pacientes com niveis séricos de progesterona igual ou superior a $6,5 \mathrm{ng} / \mathrm{mL}$. O espécime foi fixado em formol a $10 \%$, corado por hematoxilina-eosina e incubado com anticorpo monoclonal Ki-67 (clone S5). Contaram-se no mínimo 500 células, coradas ou não, por microscopia ótica (400X), utilizando sistema de captura de imagem. Resultados: os grupos I e II foram considerados homogêneos em relação às variáveis: idade da paciente $(p=0,684)$, menarca $(p=0,178)$ e volume do tumor $(p=0,205)$. As médias das percentagens de núcleos corados pelo Ki-67 foram 10,9 $(\mathrm{DP}=5,1)$ e 1,2 $(\mathrm{DP}=1,0)$ para os Grupos I e II, respectivamente. A análise estatística pelo teste $t$ de Student mostrou redução significante dos núcleos corados marcados pelo Ki-67 no Grupo II em relação ao Grupo I ( $\mathrm{p}<0,001)$. Conclusão: o raloxifeno na dose de 60mg/ dia, após 22 dias de tratamento, reduziu significantemente a proliferação celular do epitélio mamário normal de mulheres no menacme.

PALAVRAS-CHAVE: Proliferação celular; SERM; Fibroadenoma; Mama: doenças benignas; Mama: câncer 